\title{
ACTIVITIES IN ENGLISH CLASSES INDUCING POSITIVE I NEGATIVE EMOTIONS
}

\author{
Z. Kralova \\ Constantine the Philosopher University in Nitra, Nitra, Slovakia; \\ Tomas Bata University in Zlin, Zlin, Czech Republic. \\ E-mail: zkralova@ukf.sk \\ E. Kovacikova ${ }^{1}$, V. Repova ${ }^{2}$ \\ Constantine the Philosopher University in Nitra, Nitra, Slovakia. \\ E-mail: ${ }^{1}$ ekovacikova@ukf.sk; ${ }^{2}$ veronika.repova@student.ukf.sk \\ E. Skorvagova \\ University of Zilina, Zilina, Slovakia. \\ E-mail: eva.skorvagova@fhv.uniza.sk
}

\begin{abstract}
Introduction. Emotions have been proven to have significant impact on cognitive and motivational aspects of learning. Choosing appropriate activities to stimulate learners' positive emotions can thus greatly promote learning.

Aim. The present research is aimed to find out which learning activities induce positive / negative emotions among upper secondary level learners of English as a foreign language and the secondary aim was to identify the emotions experienced.

Methodology and research methods. Methodological triangulation applying qualitative research methods (questionnaire, interview and observation) was conducted among 62 learners and their 2 English teachers. A complementary quantitative instrument (scale) was used to detect the subjective emotional comfort of learners during English lessons.

Results. The findings revealed prevailing positive habitual comfort of learners and joy as their primary emotion incited mostly by communication activities. Negative emotions of fear and sadness were detected mainly during testing and evaluation.

Scientific novelty. The combination of four research methods in a combined research design studying the complex scale of emotions related to learning a foreign language has not been applied yet.

Practical significance. Greater understanding of the affective aspect in learning a foreign language which may help foreign language teachers and methodologists select the appropriate activities to effectively address the actual cognitive and affective needs of learners.
\end{abstract}

Keywords: English, foreign language, emotions, learning activities, upper secondary level.

Acknowledgements. This work was supported by the Cultural and Educational Grant Agency of the Ministry of Education, Science, Research and Sport of the Slovak Republic (KEGA 002UKF-4/2020). 
For citation: Kralova Z., Kovacikova E., Repova V., Skorvagova E. Activities in English classes inducing positive / negative emotions. The Education and Science Journal. 2021; 23 (1): 136-155. DOI: 10.17853/1994-5639-2021-1-136-155

\title{
ВИДЫ ДЕЯТЕЛЬНОСТИ НА УРОКАХ АНГЛИЙСКОГО ЯЗЫКА, ВЫЗЫВАЮЩИЕ ПОЛОЖИТЕЛЬНЫЕ / ОТРИЦАТЕЛЬНЫЕ ЭМОЦИИ
}

\author{
Университет им. Константина Философа в Нитре, Нитра, Словакия; \\ 3. Кралова \\ Университет Томаша Бати в Злине, Злин, Чешская Республика. \\ E-mail: zkralova@ukf.sk \\ Е. Ковачикова' \\ Университет им. Константина Философа в Нитре, Нитра, Словакия. \\ E-mail: ${ }^{1}$ ekovacikova@ukf.sk; ${ }^{2}$ veronika.repova@student.ukf.sk \\ Е. Шкорвагова \\ Жилинский университет, Жилина, Словакия. \\ E-mail: eva.skorvagova@fhv.uniza.sk
}

\begin{abstract}
Аннотаиия. Введение. Доказано, что эмоции оказывают существенное влияние на когнитивные и мотивационные аспекты обучения. Таким образом, выбор подходящих занятий дмя стимулирования положительных эмоций школьников может в значительной степени способствовать обучению.

Цель. Основная цель исследования заключалась в том, чтобы выяснить, какие виды учебной деятельности вызывают положительные, а какие - отрицательные эмоции у старшеклассников, изучающих английский язык как иностранный. Второстепенной целью было выявление испытываемых эмоций.

Методология и методы. Методомогическая триангуяяция с применением качественных методов исследования (анкетирование, интервью и наблюдение) быма проведена среди учащихся $(\mathrm{n}=62)$ и их учителей английского языка $(\mathrm{n}=2)$. Дополнительный количественный инструмент (шкала) использовался для определения субъективного эмоционального комфорта школьников во время уроков английского языка.

Результаты. Результаты показали, что у учащихся преобладают позитивный привычный комфорт и радость как кАючевая эмоция, вызванная в основном коммуникативной деятельностью. Отрицательные эмоции (страх и печаль) выявцялись преимущественно во время тестирования и оценивания.

Научная новизна состоит в том, что впервые применялось сочетание четырех методов в комбинированном дизайне исследования сложной шкалы эмоций, связанных с изучением иностранного языка.

Практическая значимость. Аучшее понимание аффективного аспекта в изучении иностранного языка может помочь педагогам и методистам в выборе подходящих занятий дмя эффективного удовлетворения реальных когнитивных и эмоциональных потребностей учащихся.
\end{abstract}

Образование и наука. Том 23, № 1. 2021 / The Education and Science Journal. Vol. 23, № 1. 2021 
Ключевые слова: английский язык, иностранный язык, эмоции, учебные занятия, средняя шкома.

Благодарности. Статья поддержана Агентством культурных и образовательных грантов Министерства образования, науки, исследований и спорта Словацкой Республики (KEGA 002UKF-4/2020).

Для иитирования: Кралова 3., Ковачикова Е., Репова В., Шкорвагова Е. Виды деятельности на уроках английского языка, вызывающие положительные / отрицательные эмоции // Образование и наука. 2021. T. 23, № 1. C. 136-155. DOI: 10.17853/1994-56392021-1-136-155

\section{Introduction}

Emotions are generally understood as a complex psychophysiological experience induced as a result of our interactions with the environment ${ }^{1}$. Their classification has been attempted from different perspectives and the known models, e.g. [1-6] more or less correspond to the theory of universal emotions [2], and the most common taxonomies of emotions reflect their positive-negative polarity [7, 8]. Mostly positive emotions have the ability to "broaden people's momentary thought-action repertoires and build their enduring personal resources, ranging from physical and intellectual resources to social and psychological resources" [9, p. 219].

After affective factors being recognised as equally relevant in learning as cognitive factors in the second half of the twentieth century, the research in foreign language learning has overwhelmingly concentrated on negative emotions such as anxiety [10]. The impetus for consideration of the role of positive emotions (foreign language enjoyment) in language pedagogy has been supported by the developments in positive psychology mostly after 2000 [11].

As language is strongly related to human identity, it is natural that language classrooms are abundant with a wide scale of emotions. However, it was only very recently that a few researchers started to investigate discrete emotions related to foreign language learning [12, 13]. To the best of the authors' knowledge, there have not yet been any studies exploring the complex scale of emotions related to foreign language learning applying both qualitative and quantitative research methods. The current study investigates broad spectrum of affective experiences tied directly to foreign language learning activities [14] in a mixed cross-sectional and longitudinal research design.

${ }^{1}$ The Psychology Notes HQ - online resources for psychology students. Theories of emotion in psychology [Internet]. Psychology Notes HQ; 2020 [cited 2020 Apr 13]. Available from: https://www.psychologynoteshq.com/theoriesofemotion/ 


\section{Literature Review}

Starting with the classical Affective Filter Hypothesis [15], it has been proven many times that affective engagement of learners significantly influences learning [16]. When learners experience positive emotions during the process of learning, it can raise their consciousness of input [17, 18]. What is more, emotional components of experience persist longer in memory and are recalled with greater accuracy and readiness which is caused by the amygdala releasing the transmitters essential for memory [19-21].

Emotions have not only cognitive, but also motivational impact on learning. Experiencing positive emotions during learning can contribute to intrinsic motivation while the learners with the prevalence of negative emotions tend to be motivated more by extrinsic factors [22]. What is more, positive emotions engage students socially and they are more willing to communicate and get involved in class activities. Thanks to affect involved through the right choice of activities, learners are more willing to invest their energy and attention in the learning process [23].

Learners' cognitive investment in, active participation with, and emotional commitment to learning [24] are described through intellectual, emotional, behavioral, physical, social and cultural engagement ${ }^{1}$. [25] provides an overview of engagement strategies and teaching tips how to increase learners' involvement such as: hold a meaningful conversation, turn on some music, make learning content personal, use technology, give students some choices, create challenging activities, use movement to make learning active, make it a game, focus on clearly stated goals, use an activating task, limit the lecture, use graphics and illustrations, focus on higher-order thinking, and summarise the work at the end.

Nevertheless, negative emotions are also inevitable part of learning [22]. Emotional learning spiral [26] takes into account all four phases of learning: students feel great until they are confronted with confusion or challenging information; the feelings of being confused and anxious are present as the new information is hard to understand; frustration occurs as the new thing is still not learnt and only brings difficulties; and finally, understanding of a new concept comes and with it also determination, hopefulness and satisfaction.

Learners' engagement is strongly related to teacher's commitment which motivates the teacher to search for the best teaching methods that can influence students' engagement, efforts and self-confidence [27]. New social demands have redefined the way foreign language teachers develop their in-class roles and activities towards learner-centered and reflective teaching [28]. Selecting

1 The glossary of education reform [Internet]. Student engagement. Portland: Great Schools Partnership; 2016 [cited 2020 May 23]. Available from: https://www.edglossary.org 
the appropriate activities to effectively address the actual cognitive and affective needs of learners and promote learning is thus paramount in current educational context.

\section{Materials and Methods}

\section{Objectives}

The primary research objective was to find out which learning activities induce positive/negative emotions among upper secondary level learners in English as a foreign language (EFL) classes. The secondary aim was to identify the emotions experienced. Methodological triangulation applying qualitative research methods (questionnaire, interview and observation) was conducted to reveal the parallels and differences that the individual methods may bring. The complementary quantitative method (scale) was applied to obtain a more complex picture of learners' emotions experienced during EFL classes.

In this context, four research questions were formulated:

1. What emotions induced by specific EFL learning activities are selfperceived by learners?

2. What learners' emotions induced by specific EFL learning activities are perceived by teachers?

3. What learners' emotions induced by specific EFL learning activities are observed by a psychologist and an educationist?

4. What is the relationship of the above-mentioned findings?

\section{Participants}

62 EFL upper secondary Slovak students served as participants in this study. They shared an additional number of variables such as the level of English proficiency (B1-B2), age (15-18 years), onset age of EFL learning (10-12 years), prevailing formal school training in English and a comparable amount of experience in an English-speaking environment (no longer than several days). The participants, as middle adolescent learners [29], develop their metacognition and reflective thinking and their ability to recognise and verbalise emotions increases [30]. Therefore, upper secondary level learners were considered suitable respondents for the study of emotions associated with foreign language learning. Two EFL teachers (7- and 11-year TEFL experience) teaching the participants were also involved in the research.

\section{Instruments}

The instruments were administered with the participants in their native language and in the sequence mentioned below. The research objectives were 
thematised and transformed into the direct form questions. Both learners and teachers were enabled to answer the questions in their own words and thus produced unstructured responses. Then, the answers were analysed by generating and systematising according to the selected standardised classification criteria [4, 31].

\section{Questionnaire}

The main aim of the questionnaire was to find out what emotions learners experience doing various activities in English lessons. The questionnaire consisted of four open questions:

1. In which activities during English lessons do you usually experience positive emotions?

2. Will you specify the positive emotions?

3. In which activities during English lessons do you usually experience negative emotions?

4. Will you specify the negative emotions?

\section{Scale}

The Emotional Habitual Subjective Comfort Scale (EHCS) is a concise and reliable instrument created and verified by psychologists [32] for detecting the self-reflected frequency of experiencing positive and negative emotions and physical feelings (See Appendix A). The scale contains four items classifying positive emotions - joy, happiness, delight, physical vigor $(\mathrm{a}=0.67-0.80$, stability coefficient $r=0.63$ ) and six negative emotions - shame, sense of guilt, fear, sadness, pain, anger $(a=0.68-0.74$, stability coefficient $r=0.66)$ with their inter-correlation coefficient $\mathrm{r}=-0.23$.

The scale required participants to indicate the frequency of experiencing the given emotions in English lessons in a 6-point Likert scale. Points were related to varying degrees, 6 points representing 'almost always', 5 points 'very often', 4 points - 'often', 3 points - 'sometimes', 2 points - 'seldom' and 1 point - 'almost never'. The ratio 1 indicated overall positive comfort, 2 - negative comfort, 3 - positive and negative comfort.

\section{Interview}

Subsequently, the interview was conducted with two English teachers teaching the participants. They were asked similar questions as the learners to find out their perspective on the students' emotional experiencing. The interview was conducted in a face-to-face format. The interviewer (one of the authors) informed each participant about the purpose and conduction of the interview and asked for permission to record the responses. The interviewers considered 
also some prompts to clarify their questions and probes to ask participants to provide details for their responses, if needed.

1. In which activities during English lessons do students usually experience positive emotions?

2. Will you specify the positive emotions?

3. In which activities during English lessons do students usually experience negative emotions?

4. Will you specify the negative emotions?

\section{Observation}

The participants' classroom activities and expressed emotions were directly observed by an experienced EFL teacher and a psychologist (the authors) in 16 English lessons during a period of two months. The activities done during the lessons were monitored, as well as students' emotional experiencing deduced from their behavior, facial expressions and body language. The symptoms were then interpreted by the psychologist and attributed to specific emotions.

\section{Group Interview}

Finally, a group interview of semi-structured type with participating students divided into five focus groups of 11-14 was conducted to clarify, explain or illustrate the findings obtained by the instruments previously applied (see the Discussion section). The interviewer (one of the authors) informed each participant about the purpose of the interview and asked for permission to record the responses. The students were also encouraged do discuss the issues not yet been addressed.

\section{Results and Discussion}

\section{Questionnaire}

The students named ten activities inducing positive emotions $\left(f_{i}=0.62\right)$ and seven activities inducing negative emotions $\left(f_{i}=0.70\right)$. Communication activities (dialogue, discussion, conversation) and cooperation activities (pair work and group work) were most positively appreciated while testing activities and grammar-focused activities invoked mainly negative feelings (Table 1).

Generally, skill/fluency/content-oriented activities [31,33] were rather positively reported by the students $(63.2 \%)$ while system/accuracy/formoriented activities $[31,33]$ were perceived mostly negatively $(81.0 \%)$. Concerning communicative language activities ${ }^{1}$, students enjoyed spoken interaction

\footnotetext{
${ }^{1}$ CEFR (Common European framework of reference for languages: Learning, teaching, assessment - Companion volume with new descriptors [Internet]. Strasbourg: Council of Europe; 2018. [cited 2020 April 7]. Available from: www.coe.int/lang-cefr
} 
$(82.3 \%)$ and production (62.9\%). Interestingly, none of them marked reception activities as positive (54.8\% had negative attitude to listening to instructions). Depending on the level of control, written production was evaluated both positively (free creative writing - 33.9\%) and negatively (guided essay writing - 61.3\%). Concerning the form of work, pair and group work were included in positive activities $(75.8 \%)$ and nobody explicitly mentioned individual or whole class activities.

The learners reported positive feelings more often $\left(f_{i}=0.60\right)$ than the negative ones $\left(f_{i}=0.27\right)$. Two thirds of self-perceived positive emotions could be attributed to the primary emotion "joy" (with the significant dominance of contributing secondary emotions "relief" and "zest") and one third to the primary emotion "love". Concerning negative emotions, more than one third of participants identified primary emotion "fear" (contributed nearly equally by the secondary emotions "horror" and "nervousness") and less students stated "sadness" and "anger" (Figure 1).

Table 1

The activities and emotions detected by the questionnaire

\begin{tabular}{|c|c|c|c|c|c|c|c|}
\hline \multicolumn{4}{|c|}{ POSITIVE EMOTIONS } & \multicolumn{4}{|c|}{ NEGATIVE EMOTIONS } \\
\hline activity & ni & $\begin{array}{c}\text { self-perceived } \\
\text { emotion }\end{array}$ & ni & activity & ni & $\begin{array}{l}\text { self-perceived } \\
\text { emotion }\end{array}$ & ni \\
\hline dialogue & 58 & relaxation & 56 & oral test & 54 & fear & 30 \\
\hline discussion & 56 & happiness & 52 & written test & 50 & tenseness & 29 \\
\hline conversation & 53 & pleasure & 49 & unexpected test & 50 & stress & 25 \\
\hline pair work & 49 & motivation & 47 & grammar exercise & 47 & horror & 21 \\
\hline group work & 45 & interest & 43 & essay & 38 & depression & 20 \\
\hline online exercise & 37 & confidence & 38 & lecture & 34 & apprehension & 19 \\
\hline creative task & 29 & cheerfulness & 37 & written exercise & 29 & sadness & 16 \\
\hline opinion writing & 21 & contentment & 33 & & & anxiety & 13 \\
\hline game & 18 & joy & 27 & & & suffering & 10 \\
\hline storytelling & 18 & satisfaction & 26 & & & despair & 8 \\
\hline & & amusement & 21 & & & anger & 4 \\
\hline & & fascination & 18 & & & disappointment & 3 \\
\hline
\end{tabular}




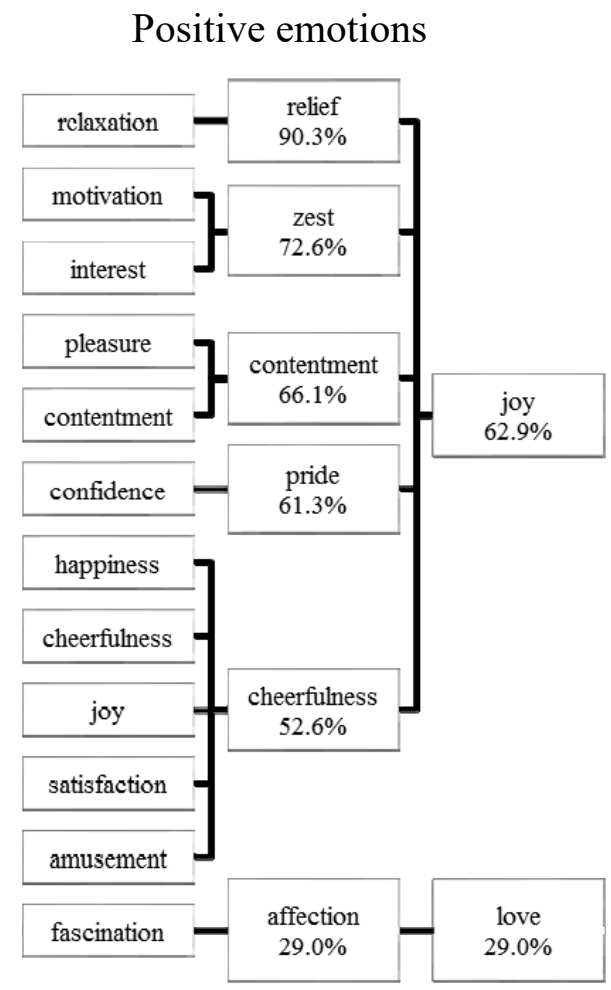

Negative emotions
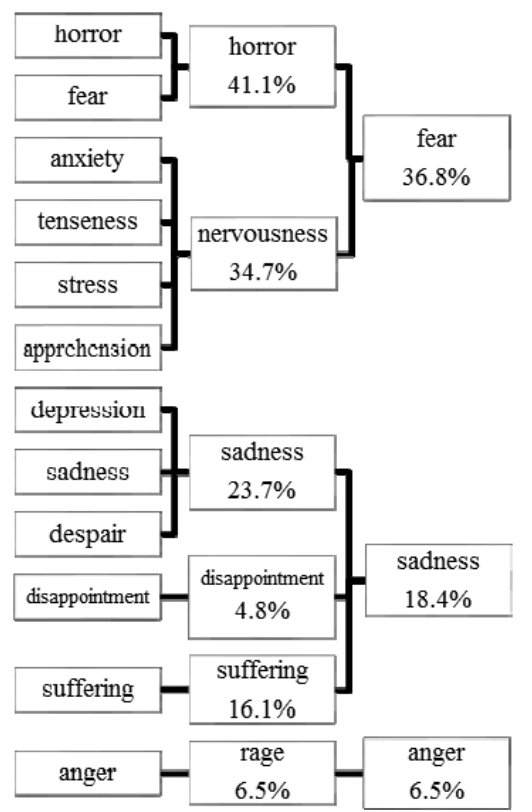

Fig. 1. The structure of emotions detected by the questionnaire

\section{Interview}

Both teachers named cooperation-based and opinion-based tasks (spoken production and interaction and creative written production) among activities inducing positive emotions. Surprisingly, teachers did not realise that writing essays is reflected negatively by more than a half of their students. Similarly to students' opinions, the teachers considered testing and evaluation as activities in which students feel and express negative emotions. On the other hand, they thought the reception activities (listening and reading comprehension) were perceived positively by their students who mostly classified them as neutral during final group interview (Table 2).

Identically to students' self-perceptions, the teachers perceived "joy" as a dominant positive emotion and prevailing negative emotions "fear", "sadness" and "anger" among their students. While secondary emotions feeding the primary emotions of "fear" and "anger" corresponded with the learners' statements, the secondary emotion contributing to "sadness" was perceived as "neglect" by the teachers (Figure 2). 
The activities and emotions detected by the interview

\begin{tabular}{|l|l|l|l|}
\hline \multicolumn{2}{|c|}{ POSITIVE EMOTIONS } & \multicolumn{2}{c|}{ NEGATIVE EMOTIONS } \\
\hline \multicolumn{1}{|c|}{ activity } & perceived emotion & \multicolumn{1}{c|}{ activity } & perceived emotion \\
\hline $\begin{array}{l}\text { creative task } \\
\text { dialogue } \\
\text { discussion } \\
\text { conversation } \\
\text { pair work } \\
\text { game } \\
\text { storytelling } \\
\text { opinion writing } \\
\text { opinion talk } \\
\text { listening } \\
\text { reading }\end{array}$ & $\begin{array}{l}\text { cheerfulness } \\
\text { happiness } \\
\text { satisfaction } \\
\text { relaxation }\end{array}$ & $\begin{array}{l}\text { oral test } \\
\text { written test } \\
\text { evaluation }\end{array}$ & $\begin{array}{l}\text { anxiety } \\
\text { fear } \\
\text { anger } \\
\text { insecurity } \\
\text { boredom } \\
\text { embarrassment } \\
\text { indifference }\end{array}$ \\
\hline
\end{tabular}

Positive emotions

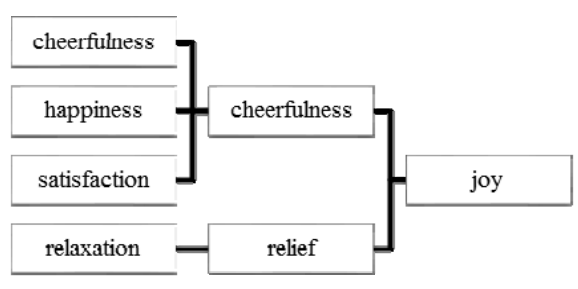

Negative emotions

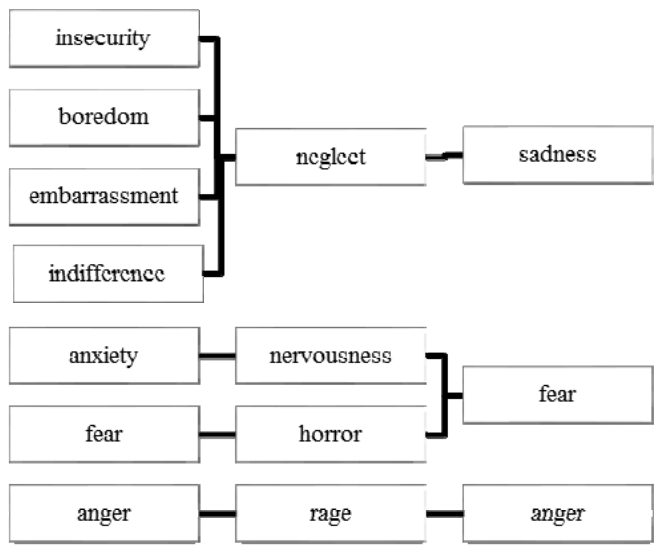

Fig. 2. The structure of emotions detected by the interview

\section{Observation}

Based on classroom observation, the activities evoking mainly positive emotions were communication-based activities (dialogue, discussion and brainstorming), cooperation activities (pair work) and audio-visual activities (picture description, songs and videos) (Table 3). During these activities, most of the students seemed to experience interest, amusement, confidence, satisfaction, pleasure, acceptance and contentment which can be attributed to the primary emotion "joy" (Figure 3). 
On the other hand, teachers' monologue, a short test or completing grammar exercises were accompanied by looking down when a question came up, evasive look, lack of eye contact, shaking voice, delayed answers, refusing body language, frowning and gazing which were interpreted by a psychologist most often as the symptoms of insecurity and worry contributing to the primary emotions "sadness" and "fear". Boredom was frequently observed during frontal explanation which was also reflected in the teachers' interview though students did not admit experiencing boredom.

Activities supported by audio-visual materials (watching videos, listening to and singing songs) were connected with apparent positive reactions of the students. Nevertheless, neither students nor teachers mentioned such activities because they were only rarely included in the lessons as it was explained in group interview. Longer writing production was not observed as it was usually covered by homework.

Table 3

The activities and emotions detected by the observation

\begin{tabular}{|l|l|l|l|}
\hline \multicolumn{2}{|c|}{ POSITIVE EMOTIONS } & \multicolumn{2}{c|}{ NEGATIVE EMOTIONS } \\
\hline \multicolumn{1}{|c|}{ activity } & observed emotion & \multicolumn{1}{c|}{ activity } & observed emotion \\
\hline dialogue & cheerfulness & grammar exercise & boredom \\
discussion & happiness & written test & insecurity \\
brainstorming & satisfaction & lecture & sadness \\
disappointment \\
pair work & joy & & worry \\
picture description & contentment & & fear \\
video & pleasure & & \\
song & relaxation & & \\
\hline
\end{tabular}

Positive emotions

Negative emotions
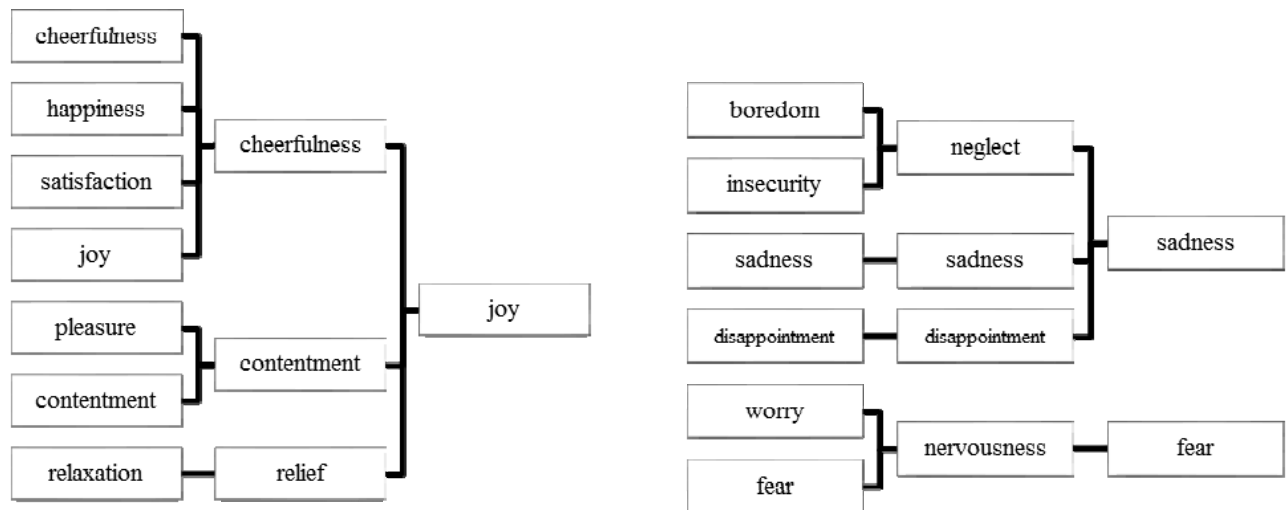

Fig. 3. The structure of emotions detected by the observation 


\section{Scale}

The mean scores obtained (see Appendix B) reflected prevailing positive habitual comfort of the participants during English lessons (positive comfort 4.00 , negative comfort -2.57 , ratio -1.42 ).

The data obtained by all three research instruments correspond with some previous research findings, e.g. [25] proving that the most positively perceived learning activities are those increasing learners' involvement - spoken production and interaction, especially when their content is meaningful and personalised for learners (as specified in group interview). And indeed, it was observed that when the students felt connected to the topic, most of them participated actively.

The importance of students' engagement going hand in hand with motivation (emphasised already by [34]) were supported by the teachers as well. They pointed out the atmosphere of acceptance conducive to the expression of students' opinions, awareness of learners about the aims and conduct of the lesson, encouragement and effort materialised in results. As one of the teachers said: "It's great when students realise that the responsibility for learning is in their hands," adding that even boring grammatical drill exercises are accepted by students when they know their purpose. As it was concluded several times [22], positive emotions are key to motivation and motivation makes learning meaningful and brings emotional fulfilment.

It was a gratifying finding during the observation that teachers did not only verbalise but, in particular, performed the above-mentioned strategies. The observed lessons usually started with a small talk which tuned students to a positive wave and informed them about the goal of the lesson, then turned into a short game or brainstorming to summon the already mastered knowledge needed for the rest of the lesson.

Testing and evaluation were generally perceived negatively by the students. Here, one of the teachers interviewed saw the difference between younger (1516 years old) and older (17-18 years of age) upper secondary level students. The younger ones seemed to be more afraid of oral testing because they were ashamed of mistakes made in front of their peers. While older students were usually more nervous about written tests as they were more concerned with their marks towards the end of their study. However, both teachers agreed that learners' positive or negative emotions were directly related to their language competence and achievement.

The triangulation of methods detected "joy" as the dominant primary positive emotion experienced in EFL classes substantiated by the students in group interview as follows "we have a good teacher; English is my favourite subject; the topic is interesting; pleasant atmosphere and fun in class" and by 
the observed smile or laugh, direct eye contact, focused look and relaxed body. Negative emotions of "sadness" and "fear" indicated by the students and teachers were explained by "unpredictable lesson structure; uninteresting topic or exercises; I am not prepared for the lesson; I do not have good knowledge of English; I do not understand what to do". "Anger" exclusively related to testing and evaluating was not detected during observation which might be explained by the "observer effect".

Striking discrepancy between students' and teachers' points of view was in decoding the emotions. While students stated that they perceived negative emotions like depression, sadness, despair, disappointment and suffering (as they explained, resulting mostly from their self-perceived poor language command), teachers understood those as boredom, embarrassment and indifference.

However, classroom observation proved both sides right - the psychologist identified symptoms of emotions contributing both to "sadness" and "neglect". Students' typical reactions to helplessness in fulfilling the activity were resignation and passivity manifested by disgusted facial expression in the form of shrinking nose, the raise of cheeks and upper lip and a sigh. On the other hand, students who performed their tasks sooner and were waiting for the others often showed signs of boredom and restlessness.

Nevertheless, teaching today is extremely demanding, both cognitively and emotionally, and teachers usually do not have time and space to decode all internal feelings of their students, i.e. frequent positive emotions "contentment" and "pride" with dominant internal processing were, understandably, unnoted by the teachers. Yet teacher is the key factor in creating the classroom atmosphere [10] - "even a boring subject can be great if a teacher is great," one of the students said in group interview. That is why, practical psychology should be a consistent and continuous part of pre-service and in-service teacher training. Unfortunately, it is often provided solely in the form of theoretical lectures [35].

\section{Conclusion}

It can be summarised that activities aimed at implicit learning of language were accepted more positively than those fostering the explicit learning, and semi-guided or free activities incited more positive emotions than rule-based tasks. The current findings correspond to major adolescent characteristics they are eager to learn about topics they find interesting and useful, interested in real-life experiences and authentic learning opportunities, they favour active over passive learning, prefer interactions with peers during educational activities and are highly sensitive to criticism [36].

Therefore, they should be supplied with authentic educational activities (e.g., experimentation, analysis and synthesis of data) that are meaningful for 
them and that foster their need to interact directly with their world - through discourse with peers and adults and hands-on experience [37].

Learning a language is different from learning other subjects (cf. "relaxation" was the attribute identified by all three research instruments) it is based on communication which is strongly related to our identity. When learning a language is enjoyable it can enhance our overall well-being which is in line with current individualised, customised [38] and character-building [39] approaches in pedagogy.

\section{Limitations}

The overall findings of this study must be interpreted in the light of several limitations. The first one is the space limit, which precluded publishing all data on all parts of the research in a single article. The study presents partial data from a larger longitudinal study which could offer additional perspectives on the issue.

The second limitation is the small sample size. Though the group showed clear tendencies in the data, larger one may allow findings to emerge more clearly. Finally, future research may want to verify the issue also in other age-groups of learners, the correlation of foreign language achievement and emotions and not least the emotions experienced by teachers.

Although we are aware of the impossibility of achieving total objectivity in this type of research, the objectivity was maximised through the combination of research methods. In spite of these limitations, it is hoped that another small step has been taken towards a greater understanding of the affective aspect in learning a foreign language.

\section{References}

1. Tomkins S. Affect theory. Approaches to Emotion. 1984; 163: 163-195.

2. Ekman P. Are there basic emotions? Psychological Review. 1992; 99 (3): 550-553.

3. Plutchik R. The nature of emotions. American Scientist. 2001; 89 (4): 344-350.

4. Parrott W. Emotions in social psychology. Key readings in social psychology. Philadelphia: Psychology Press; 2001.

5. Izard C. Forms and functions of emotions: Matters of emotion - cognition interactions. Emotion Review. 2011; 3 (4): 371-378.

6. Frederickson B. Positive emotions broaden and build. Advances in Experimental Social Psychology. 2013; 47: 1-53.

7. Desmet P. M. A. Faces of product pleasure: 25 positive emotions in humanproduct interactions. International Journal of Design. 2012; 6 (2): 1-29.

8. Fokkinga S. Negative emotion typology [Internet]. [cited 2020 Mar 14]. Available from: https://diopd.org/negative-emotion-typology/ 
9. Frederickson B. L. The value of positive emotions. American Scientist. 2003; 91: 330-335.

10. Horwitz E., Horwitz M., Cope J. Foreign language classroom anxiety. The Modern Language Journal. 1986; 70 (2): 125-132.

11. Dewaele J. M., MacIntyre P. The two faces of Janus? Anxiety and enjoyment in the foreign language classroom. Studies in Second Language Learning and Teaching. 2014; 4 (2): 237-274.

12. Teimouri Y. Differential roles of shame and guilt in L2 learning: How bad is bad? The Modern Language Journal. 2018; 102 (4): 632-652.

13. Pekrun R., Hall N. C., Goetz T., Perry R. P. Boredom and academic achievement: Testing a model of reciprocal causation. Journal of Educational Psychology. 2014; 106 (3): 696-710.

14. Shao K., Pekrun R., Nicholson L. J. Emotions in classroom language learning: What can we learn from achievement emotion research? System. 2019; 86: $102-121$.

15. Krashen S. D. Principles and practice in second language acquisition. New York: Prentice-Hall; 1982.

16. Lewis M. Bridging emotion theory and neurobiology through dynamic systems modeling. Behavior and Brain Sciences. 2005; 28: 169-245.

17. Kamenicka J., Kovacikova E. Emotional engagement in teaching English vocabulary. Prague: Verbum; 2019. 138 p.

18. Boudreau C., MacIntyre P., Dewaele J. M. Enjoyment and anxiety in second language communication: An idiodynamic approach. Studies in Second Language Learning and Teaching. 2018; 8 (1): 149-170.

19. Medina J. Brain rules. Seattle: Pear Press; 2008. 320 p.

20. Todd R. Discussion with Carmine Gallo. In: Gallo C. (ed.). Talk like TED. New York: Macmillan; 2014. p. 140-143.

21. Gallo C. Talk like TED. New York: Macmillan; 2014. 288 p.

22. Drew C. What is the importance of emotions in education \& learning? Helpful Professor.com; 2020 [cited 2020 Apr 14]. Available from: https:// helpfulprofessor.com/emotion-in-education/

23. Bolitho R., Carter R., Hughes R., Ivanic R., Masuhara H., Tomlinson B. Ten questions about language awareness. ELT Journal. 2003; 57 (3): 251-259.

24. Zepke N., Leach L. Improving student engagement: Ten proposals for action. Active Learning in Higher Education. 2010; 11 (3): 167-77.

25. Bender W. N. 20 strategies for increasing student engagement. West Palm Beach: Learning Sciences; 2017. 244 p.

26. Kort B., Reilly R., Picard R. W. An affective model of interplay between emotions and learning: Reengineering educational pedagogy - Building a learning companion. In: IEEE International Conference on Advanced Learning Technologies; 2001. IEEE Computer Society; 2001. 0043.

27. Bakker A. B., Schaufeli W. B. Positive organizational behavior: Engaged employees in flourishing organizations. Journal of Organizational Behavior. 2008; 29 (2): 147-154. 
28. Cecilia R. R., Lopez A. New trends in foreign language teaching: Methods, evaluation and innovation. Cambridge: Cambridge Scholars Publishing; 2018.

29. Allen B., Waterman H. Stages of adolescence [Internet]. 2019 [cited May 12]. Available from: https://www.healthychildren.org/English/ages-stages/teen/ Pages/Stages-of-Adolescence.aspx

30. Manning M. L. Havighurst' developmental tasks, young adolescents, and diversity. Journal of Educational Strategies, Issues and Ideas. 2002; 76 (2): 75-78.

31. Scrivener J. Learning teaching. Oxford: Macmillan Education; 2011. 144 p.

32. Dzuka J., Dalbert C. Vyvoj a overenie validity Skal emocionalnej habitualnej subjektivnej pohody (SEHP). Ceskoslovenska Psychologie. 2002; 46: 234-250. (In Slovak)

33. Brown H. D. Principles of language learning and teaching. New York: Longman; 2001. $416 \mathrm{p}$.

34. Piaget J. Intelligence and affectivity: Their relationship during child development. Palo Alto: Annual Reviews; 1981. 77 p.

35. Kralova Z., Skorvagova E., Tirpakova A., Markechova D. Reducing student teachers' foreign language pronunciation anxiety through psycho-social training. System. 2017; 65: 49-60.

36. Kellough R. D., Kellough N. G. Teaching young adolescents: Methods and resources for middle grades teaching. Upper Saddle River: Pearson Merrill Prentice Hall; 2008. 427 p.

37. Stevenson C. Teaching ten to fourteen year olds. Boston: Allyn \& Bacon; 2002. 368 p.

38. Chong C. S. Ten trends and innovations in English language teaching for 2018 [Internet]. Manchester: British Council; 2018 [cited May 10]. Available from: https://www.britishcouncil.org/voices-magazine/ten-trends-innovations-englishlanguage-teaching-2018

39. Zagvyazinsky V. I. On the barriers to the revival of Russian education. Russian Education \& Society. 2018; 60 (10-12): 775-786.

\section{Information about the authors:}

Zdena Kralova - PhD, Professor, Department of Language Pedagogy and Intercultural Studies, Constantine the Philosopher University in Nitra; Associate Professor, Department of Modern Languages and Literatures, Tomas Bata University in Zlin; ORCID 0000-0001-6900-9992; Nitra, Slovakia; Zlin, Czech Republic. E-mail: zkralova@ukf.sk

Elena Kovacikova - PhD, Assistant Professor, Department of Language Pedagogy and Intercultural Studies, Constantine the Philosopher University in Nitra; ORCID 0000-0002-3302-7141; Nitra, Slovakia. E-mail: ekovacikova@ukf.sk

Veronika Repova - Student, Study Programme "Teaching English Language and Literature", Department of Language Pedagogy and Intercultural Studies, Constantine the Philosopher University in Nitra; ORCID 0000-0002-2748-1591; Nitra, Slovakia. E-mail: veronika.repova@student.ukf.sk 
Eva Skorvagova - Dr. Sci. (Psychology), Assistant Professor, Department of Pedagogical Studies, University of Zilina; ORCID 0000-0001-8626-7539; Zilina, Slovakia. E-mail: eva.skorvagova@fhv.uniza.sk

Conflict of interest statement. The authors declare that there is no conflict of interest.

Received 12.08.2020; accepted for publication 11.11.2020.

The authors have read and approved the final manuscript.

\section{Ннформаиия об авторах:}

Кралова Здена - PhD, профессор кафедры языковой педагогики и межкультурных исследований Университета им. Константина Философа в Нитре; доцент кафедры современных языков и митератур Университета Томаша Бати в ЗАине; ORCID 0000-0001-6900-9992; Нитра, САовакия; Злин, Чехия. E-mail: zkralova@ukf.sk

Ковачикова Елена - PhD, доцент кафедры языковой педагогики и межкультурных исследований Университета им. Константина Философа в Нитре; ORCID 0000-0002-3302-7141; Нитра, Словакия. E-mail: ekovacikova@ukf.sk

Репова Вероника - студентка образовательной программы «Преподавание английского языка и митературы" кафедры языковой педагогики и межкультурных исследований Университета им. Константина Философа в Нитре; ORCID 0000-0002-2748-1591; Нитра, Словакия. E-mail: veronika.repova@student.ukf.sk

Шкорвагова Ева - доктор психологических наук, доцент кафедры педагогических исследований Жилинского университета; ORCID 0000-0001-86267539; Жилина, Словакия. E-mail: eva.skorvagova@fhv.uniza.sk

Информация о конфликте интересов. Авторы заявцяют об отсутствии конфиикта интересов.

Статья поступима в редакцию 12.08.2020; принята в печать 11.11.2020. Авторы прочитали и одобрили окончательный вариант рукописи. 
Appendix A

Emotional Habitual Subjective Comfort Scale (EHCS)

People are able to tell what they are experiencing and how they usually feel. Now, using the list of descriptive words presented below, try to answer how often you experience presented states of mind. To mark your answers, put " $\mathrm{X}$ " in the corresponding box.

\begin{tabular}{|c|c|c|c|c|c|c|c|c|c|c|}
\hline \multicolumn{5}{|c|}{ I EXPERIENCE } & \multicolumn{6}{|c|}{ I EXPERIENCE } \\
\hline $\begin{array}{l}\text { almost very } \\
\text { always often }\end{array}$ & often & $\begin{array}{l}\text { some- } \\
\text { times }\end{array}$ & $\begin{array}{l}\text { sel- } \\
\text { dom }\end{array}$ & $\begin{array}{c}\text { almost } \\
\text { never }\end{array}$ & $\begin{array}{l}\text { almost } \\
\text { always }\end{array}$ & $\begin{array}{l}\text { very } \\
\text { often }\end{array}$ & often & $\begin{array}{l}\text { some- } \\
\text { times }\end{array}$ & $\begin{array}{l}\text { sel- } \\
\text { dom }\end{array}$ & $\begin{array}{c}\text { almost } \\
\text { never }\end{array}$ \\
\hline 1. Anger & & & & & 6. Fea & & & & & \\
\hline$\square$ & $\square$ & $\square$ & $\square$ & $\square$ & $\square$ & $\square$ & $\square$ & $\square$ & $\square$ & $\square$ \\
\hline 2. Sense of & uilt & & & & 7. Pair & & & & & \\
\hline$\square$ & $\square$ & $\square$ & $\square$ & $\square$ & $\square$ & $\square$ & $\square$ & $\square$ & $\square$ & $\square$ \\
\hline 3. Delight & & & & & 8. Joy & & & & & \\
\hline$\square \quad \square$ & $\square$ & $\square$ & $\square$ & $\square$ & $\square$ & $\square$ & $\square$ & $\square$ & $\square$ & $\square$ \\
\hline 4. Shame & & & & & 9. Sad & ness & & & & \\
\hline$\square \quad \square$ & $\square$ & $\square$ & $\square$ & $\square$ & $\square$ & $\square$ & $\square$ & $\square$ & $\square$ & $\square$ \\
\hline 5. Physical & gor & & & & 10. Ha & ppine & & & & \\
\hline$\square \quad \square$ & $\square$ & $\square$ & $\square$ & $\square$ & $\square$ & $\square$ & $\square$ & $\square$ & $\square$ & $\square$ \\
\hline
\end{tabular}

The scores obtained in EHCS

\begin{tabular}{|c|c|c|c|c|c|c|c|c|c|c|c|c|c|c|c|c|}
\hline 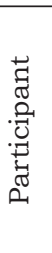 & $\begin{array}{l}\overrightarrow{D_{0}} \\
\dot{\alpha}\end{array}$ & 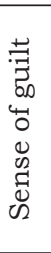 & 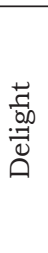 & 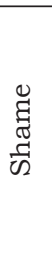 & 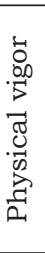 & $\begin{array}{l}\stackrel{\tilde{\varpi}}{\Phi} \\
\text { II }\end{array}$ & ڤ్ & مे & 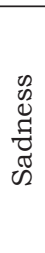 & 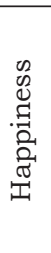 & 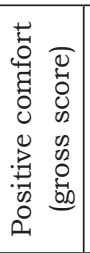 & 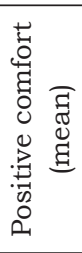 & 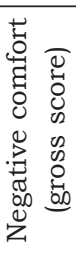 & 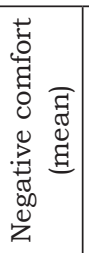 & 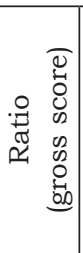 & 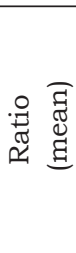 \\
\hline 1 & 4 & 3 & 2 & 1 & 2 & 3 & 3 & 3 & 5 & 2 & 9 & 2.25 & 19 & 3.17 & 2 & 2 \\
\hline 2 & 3 & 3 & 3 & 3 & 4 & 3 & 4 & 4 & 2 & 4 & 15 & 3.75 & 18 & 3 & 1 & 2 \\
\hline 3 & 3 & 2 & 3 & 2 & 5 & 3 & 3 & 5 & 3 & 5 & 18 & 4.5 & 16 & 2.67 & 1 & 1 \\
\hline 4 & 2 & 2 & 4 & 3 & 1 & 3 & 4 & 5 & 3 & 2 & 12 & 3 & 17 & 2.83 & 1 & 2 \\
\hline 5 & 2 & 2 & 3 & 1 & 3 & 3 & 2 & 4 & 3 & 5 & 15 & 3.75 & 13 & 2.17 & 1 & 1 \\
\hline 6 & 3 & 3 & 3 & 3 & 2 & 4 & 3 & 5 & 3 & 5 & 15 & 3.75 & 19 & 3.17 & 1 & 2 \\
\hline 7 & 3 & 2 & 4 & 2 & 3 & 3 & 1 & 6 & 2 & 6 & 19 & 4.75 & 13 & 2.17 & 1 & 1 \\
\hline 8 & 3 & 2 & 4 & 4 & 2 & 3 & 2 & 6 & 2 & 6 & 18 & 4.5 & 16 & 2.67 & 1 & 1 \\
\hline 9 & 2 & 3 & 3 & 3 & 5 & 3 & 1 & 5 & 1 & 5 & 18 & 4.5 & 13 & 2.17 & 1 & 1 \\
\hline
\end{tabular}




\begin{tabular}{|c|c|c|c|c|c|c|c|c|c|c|c|c|c|c|c|c|}
\hline 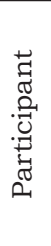 & $\begin{array}{l}\dot{y} \\
\text { 离 } \\
\dot{4}\end{array}$ & 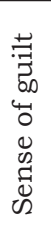 & 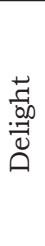 & 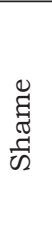 & 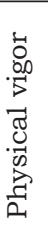 & 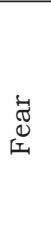 & 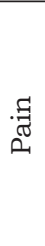 & $\overrightarrow{0}$ & 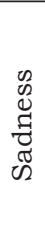 & 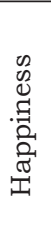 & 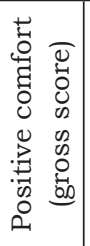 & 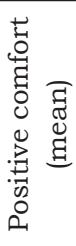 & 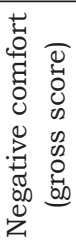 & 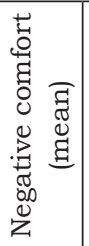 & 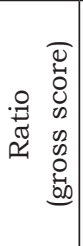 & 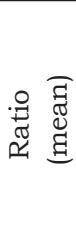 \\
\hline 10 & 2 & 2 & 3 & 2 & 4 & 3 & 2 & 4 & 3 & 5 & 17 & 4.25 & 14 & 2.33 & 1 & 1 \\
\hline 11 & 2 & 3 & 5 & 3 & 4 & 3 & 3 & 5 & 3 & 5 & 19 & 4.75 & 17 & 2.83 & 1 & 1 \\
\hline 12 & 2 & 3 & 3 & 4 & 5 & 3 & 2 & 4 & 3 & 4 & 16 & 4 & 17 & 2.83 & 1 & 2 \\
\hline 13 & 3 & 2 & 3 & 1 & 5 & 1 & 2 & 5 & 2 & 5 & 18 & 4.5 & 11 & \begin{tabular}{|l|}
1.83 \\
\end{tabular} & 1 & 1 \\
\hline 14 & 1 & 3 & 4 & 2 & 3 & 3 & 2 & 5 & 2 & 5 & 17 & 4.25 & 13 & 2.17 & 1 & 1 \\
\hline 15 & 5 & 3 & 5 & 1 & 3 & 2 & 1 & 6 & 2 & 6 & 20 & 5 & 14 & 2.33 & 1 & 1 \\
\hline 16 & 2 & 2 & 2 & 2 & 3 & 2 & 2 & 3 & 3 & 3 & 11 & 2.75 & 13 & 2.17 & 1 & 2 \\
\hline 17 & 5 & 2 & 5 & 2 & 6 & 3 & 4 & 6 & 3 & 5 & 22 & 5.5 & 19 & \begin{tabular}{|l|}
3.17 \\
\end{tabular} & 1 & 1 \\
\hline 18 & 2 & 2 & 4 & 3 & 3 & 2 & 3 & 4 & 2 & 4 & 15 & 3.75 & 14 & 2.33 & 1 & 1 \\
\hline 19 & 3 & 4 & 4 & 3 & 2 & 4 & 2 & 4 & 3 & 4 & 14 & 3.5 & 19 & 3.17 & 1 & 2 \\
\hline 20 & 3 & 2 & 3 & 2 & 4 & 3 & 3 & 4 & 3 & 4 & 15 & 3.75 & 16 & 2.67 & 1 & 2 \\
\hline 21 & 2 & 3 & 6 & 3 & 6 & 3 & 1 & 8 & 2 & 6 & 24 & 6 & 14 & 2.33 & 1 & 1 \\
\hline 22 & 3 & 3 & 3 & 4 & 3 & 4 & 2 & 5 & 3 & 4 & 15 & 3.75 & 19 & \begin{tabular}{|l|}
3.17 \\
\end{tabular} & 1 & 2 \\
\hline 23 & 3 & 2 & 4 & 3 & 3 & 3 & 2 & 5 & 2 & 6 & 18 & 4.5 & 15 & 2.5 & 1 & 1 \\
\hline 24 & 1 & 2 & 3 & 3 & 3 & 3 & 3 & 3 & 3 & 3 & 12 & 3 & 15 & 2.5 & 1 & 2 \\
\hline 25 & 2 & 2 & 4 & 1 & 5 & 3 & 3 & 5 & 2 & 6 & 20 & 5 & 13 & 2.17 & 1 & 1 \\
\hline 26 & 5 & 3 & 4 & 4 & 3 & 4 & 3 & 3 & 5 & 2 & 12 & 3 & 24 & 4 & 2 & 2 \\
\hline 27 & 3 & 4 & 3 & 2 & 3 & 3 & 2 & 4 & 3 & 4 & 14 & 3.5 & 17 & 2.83 & 1 & 2 \\
\hline 28 & 3 & 2 & 3 & 2 & 4 & 3 & 2 & 4 & 2 & 4 & 15 & 3.75 & 14 & 2.33 & 1 & 1 \\
\hline 29 & 3 & 2 & 3 & 2 & 3 & 5 & 3 & 5 & 4 & 5 & 16 & 4 & 19 & \begin{tabular}{|l|}
3.17 \\
\end{tabular} & 1 & 2 \\
\hline 30 & 3 & 3 & 3 & 4 & 2 & 4 & 3 & 4 & 4 & 4 & 13 & 3.25 & 21 & 3.5 & 2 & 2 \\
\hline 31 & 3 & 3 & 4 & 4 & 2 & 3 & 1 & 4 & 3 & 4 & 14 & 3.5 & 17 & 2.83 & 1 & 2 \\
\hline 32 & 3 & 3 & 3 & 4 & 3 & 3 & 1 & 3 & 3 & 3 & 12 & 3 & 17 & 2.83 & 1 & 2 \\
\hline 33 & 3 & 2 & 5 & 2 & 4 & 1 & 2 & 4 & 1 & 4 & 17 & 4.25 & 11 & 1.83 & 1 & 1 \\
\hline 34 & 2 & 2 & 4 & 2 & 3 & 3 & 4 & 4 & 4 & 5 & 16 & 4 & 17 & 2.83 & 1 & 2 \\
\hline 35 & 3 & 3 & 3 & 2 & 2 & 3 & 3 & 4 & 3 & 3 & 12 & 3 & 17 & 2.83 & 1 & 2 \\
\hline 36 & 2 & 2 & 3 & 2 & 3 & 3 & 3 & 5 & 2 & 5 & 16 & 4 & 14 & 2.33 & 1 & 1 \\
\hline 37 & 3 & 3 & 2 & 2 & 2 & 3 & 4 & 3 & 2 & 3 & 10 & 2.5 & 17 & 2.83 & 2 & 2 \\
\hline 38 & 3 & 2 & 3 & 3 & 2 & 3 & 3 & 4 & 2 & 3 & 12 & 3 & 16 & 2.67 & 1 & 2 \\
\hline 39 & 2 & 3 & 5 & 2 & 4 & 3 & 2 & 5 & 2 & 5 & 19 & 4.75 & 14 & 2.33 & 1 & 1 \\
\hline 40 & 3 & 2 & 5 & 2 & 6 & 1 & 1 & 5 & 2 & 5 & 21 & 5.25 & 11 & 1.83 & 1 & 1 \\
\hline 41 & 1 & 2 & 3 & 2 & 3 & 3 & 2 & 5 & 3 & 6 & 17 & 4.25 & 13 & 2.17 & 1 & 1 \\
\hline 42 & 2 & 2 & 5 & 2 & 5 & 2 & 3 & 5 & 3 & 5 & 20 & 5 & 14 & 2.33 & 1 & 1 \\
\hline 43 & 2 & 2 & 3 & 3 & 4 & 3 & 2 & 6 & 3 & 5 & 18 & 4.5 & 15 & 2.5 & 1 & 1 \\
\hline 44 & 2 & 3 & 3 & 4 & 3 & 3 & 2 & 5 & 3 & 4 & 15 & 3.75 & 17 & 2.83 & 1 & 2 \\
\hline 45 & 2 & 2 & 3 & 2 & 5 & 1 & 2 & 5 & 4 & 5 & 18 & 4.5 & 13 & 2.17 & 1 & 1 \\
\hline 46 & 2 & 3 & 4 & 2 & 4 & 1 & 2 & 5 & 2 & 6 & 19 & 4.75 & 12 & 2 & 1 & 1 \\
\hline 47 & 2 & 1 & 5 & 1 & 4 & 1 & 4 & 4 & 4 & 5 & 18 & 4.5 & 13 & 2.17 & 1 & 1 \\
\hline 48 & 3 & 3 & 4 & 2 & 4 & 3 & 2 & 4 & 4 & 4 & 16 & 4 & 17 & 2.83 & 1 & 2 \\
\hline
\end{tabular}

Образование и наука. Том 23, № 1. 2021 / The Education and Science Journal. Vol. 23, № 1. 2021 


\begin{tabular}{|c|c|c|c|c|c|c|c|c|c|c|c|c|c|c|c|c|}
\hline 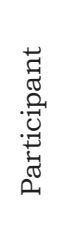 & $\begin{array}{l}\dot{4} \\
\text { क्. } \\
\dot{4}\end{array}$ & 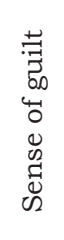 & 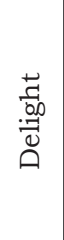 & 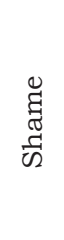 & 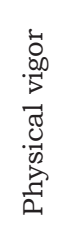 & $\begin{array}{l}\stackrel{\vec{\varpi}}{0} \\
\text { [I }\end{array}$ & . & 官 & $\begin{array}{l}0 \\
0 \\
0 \\
\tilde{D} \\
\tilde{\nabla} \\
\tilde{D}\end{array}$ & 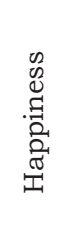 & 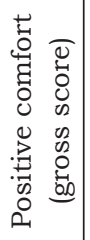 & 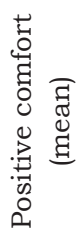 & 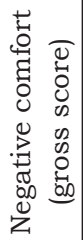 & 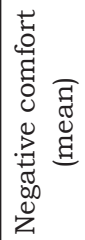 & 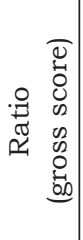 & 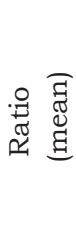 \\
\hline 49 & 3 & 3 & 5 & 2 & 6 & 3 & 4 & 6 & 3 & 5 & 22 & 5.5 & 18 & 3 & 1 & 1 \\
\hline 50 & 2 & 1 & 3 & 1 & 3 & 2 & 2 & 3 & 1 & 3 & 12 & 3 & 9 & 1.5 & 1 & 1 \\
\hline 51 & 3 & 3 & 4 & 2 & 4 & 3 & 2 & 5 & 4 & 5 & 18 & 4.5 & 17 & 2.83 & 1 & 1 \\
\hline 52 & 3 & 3 & 4 & 3 & 2 & 3 & 3 & 4 & 3 & 3 & 13 & 3.25 & 18 & 3 & 1 & 2 \\
\hline 53 & 2 & 3 & 4 & 3 & 5 & 2 & 3 & 5 & 4 & 1 & 15 & 3.75 & 17 & 2.83 & 1 & 2 \\
\hline 54 & 3 & 3 & 3 & 2 & 4 & 3 & 2 & 5 & 3 & 5 & 17 & 4.25 & 16 & 2.67 & 1 & 1 \\
\hline 55 & 5 & 3 & 4 & 2 & 3 & 2 & 3 & 5 & 1 & 6 & 18 & 4.5 & 16 & 2.67 & 1 & 1 \\
\hline 56 & 1 & 2 & 3 & 2 & 3 & 1 & 1 & 3 & 1 & 3 & 12 & 3 & 8 & \begin{tabular}{|l|}
1.33 \\
\end{tabular} & 1 & 1 \\
\hline 57 & 2 & 2 & 4 & 1 & 4 & 3 & 3 & 5 & 2 & 5 & 18 & 4.5 & 13 & 2.17 & 1 & 1 \\
\hline 58 & 5 & 2 & 3 & 4 & 3 & 2 & 1 & 5 & 4 & 4 & 15 & 3.75 & 18 & 3 & 1 & 2 \\
\hline 59 & 3 & 3 & 2 & 2 & 3 & 4 & 3 & 4 & 2 & 4 & 13 & 3.25 & 17 & 2.83 & 1 & 2 \\
\hline 60 & 3 & 1 & 4 & 3 & 4 & 4 & 2 & 4 & 2 & 4 & 16 & 4 & 15 & 2.5 & 1 & 1 \\
\hline 61 & 2 & 4 & 4 & 2 & 4 & 3 & 2 & 4 & 2 & 5 & 17 & 4.25 & 15 & 2.5 & 1 & 1 \\
\hline 62 & 2 & 2 & 3 & 2 & 4 & 2 & 2 & 4 & 2 & 3 & 14 & 3.5 & 12 & 2 & 1 & 1 \\
\hline Mean & 2.66 & 2.48 & 3.60 & 2.40 & 3.53 & 2.77 & 2.40 & 4.53 & 2.69 & 4.35 & 16.00 & 4.00 & 15.42 & 2.57 & 1.06 & 1.42 \\
\hline
\end{tabular}

